\title{
STRATEGI PUBLIC RELATIONS PESANTREN SIDOGIRI DALAM MEMBANGUN CITRA LEMBAGA PENDIDIKAN ISLAM
}

\author{
Chusnul Chotimah \\ STAIN Tulungagung, Jl. Mayor Sujadi Timur No. 46 Tulungagung, \\ chusnultata@gmail.com
}

\begin{abstract}
Pesantren has been believed to be a form of indigenous educational system in Indonesia. The history and nature of pesantren have both shown that there is a good relation between pesantren and the society. This will be the focus of the study. It would investigate the notion of how pesantren is related to the wider community, and what are its strategies to keep the community in touch with it? All this will be discussed with referring particularly to the case of pesantren Sidogiri and its already-existing unit called public relation unit. Qualitative in its nature, the paper is phenomenological in its approach. It assumes that generally speaking, any pesantren in Indonesia would -in the beginning- run by accident, and not by design. But as it grows, it becomes as modern as any advanced educational institution would be. Hence, the paper will show that pesantren Sidogiri is aware of the importance of imagebuilding, and that it consciously pursues it through its software and hardware mechanism. The paper will also show that the surrounding community and the alumni are in fact part of the pesantren's network to build a better image.
\end{abstract}

Keywords: Public relations, strategy, image, pesantren salafiyah.

\section{Pendahuluan}

Public Relations, atau dalam istilah lain lazim disebut sebagai hubungan masyarakat, adalah salah satu bagian dari upaya membentuk dan memelihara relasi yang saling menguntungkan antara organisasi dengan publiknya. Keberhasilan atau kegagalan public relations bergantung bagaimana kiat membentuk dan memelihara relasi 
tersebut. ${ }^{1}$ Dalam suatu organisasi pendidikan atau pendidikan Islam, pada hakikatnya tanpa adanya public relations sudah dapat berjalan, namun dengan tertatih-tatih dan tidak mampu berkembang dengan baik. Jefkins menyatakan bahwa public relations berarti suatu bentuk komunikasi yang berlaku terhadap semua jenis organisasi baik yang bersifat komersial maupun non-komersial, di sektor publik, pemerintah maupun swasta. ${ }^{2}$

Salah satu organisasi di Indonesia yang bergerak di bidang pendidikan dan bersifat non-profit adalah pondok pesantren. Pesantren merupakan lembaga pendidikan Islam pertama dan tertua di Indonesia keberadaannya telah banyak mendukung kelangsungan sistem pendidikan nasional. Pesantren dapat memberikan kontribusi riil karena ia mampu mencetak kader-kader intelektual yang siap untuk mengapresiasikan potensi keilmuannya di masyarakat. ${ }^{3}$ Sebagai lembaga pendidikan Islam tertua, pesantren merupakan suatu model pendidikan yang sama tuanya dengan eksistensi agama Islam di Indonesia, ia secara esktensif bertahan bahkan berkembang hingga hari ini. ${ }^{4}$ Ketahanan pondok pesantren, menurut Abdurrahman Wahid, disebabkan pola kehidupannya yang unik. ${ }^{5}$ Azyumardi Azra menilai ketahanan pesantren disebabkan oleh kultur Jawa yang mampu menyerap kebudayaan luar melalui suatu proses interiosasi tanpa kehilangan identitasnya. ${ }^{6}$ Aya Sofia mengklaim bahwa ketahanan pondok pesantren disebabkan karena jiwa dan semangat

1 Mujamil Qomar, Manajemen Pendidikan Islam: Strategi Baru Pengelolaan Lembaga Pendidikan Islam (Jakarta: Erlangga, 2007), 32.

${ }^{2}$ Frank Jefkins, Public Relations, terj. Aris Munandar (Jakarta: Erlangga, 1992), 2.

3 Imam Tolkhah dan Barizi, Membuka Jendela Pendidikan Mengurai Akar Tradisi (Jakarta: PT. Raja Grafindo Persada: 2004), 49.

4 Sunyoto, "Pondok Pesantren dalam Alam Pendidikan Nasional", dalam M. Dawam Rahardjo (ed.), Pesantren Pembaharuan (t.tp.: LP3ES, 1995), 65; Marwan Saridjo, et al., Sejarah Pondok Pesantren di Indonesia (Jakarta: Dharma Bhakti, 1982), 7; Ali Haidar, Nabdlatul Ulama dan Islam di Indonesia: Pendekatan Fiqh dalam Politik (Jakarta: PT. Gramedia Pustaka Utama, 1994), 84.

5 Abdurrahman Wahid, "Pesantren sebagai Subkultur", dalam Rahardjo (ed.), Pesantren dan Pembaharuan, 32.

6 Azyumardi Azra, "Surau di Tengah Krisis: Pesantren dan Perspektif Masyarakat", dalam Dawam Rahardjo (ed.), Pergulatan Dunia Pesantren: Membangun dari Bawah (Jakarta: LP3ES, 1985), 173. 
kewiraswastaan yang tinggi. ${ }^{7}$ Hasan Langgulung mengamati ketahanan pesantren sebagai akibat dari pribadi-pribadi kiai yang menonjol dengan ilmu dan visinya. ${ }^{8}$ Sedangkan Ma'shum melaporkan ketahanan pesantren akibat dari dampak positif dari kemampuan melahirkan berbagai daya guna bagi masyarakat.'

Ketahanan pondok pesantren menjadi hal yang unik dan menarik untuk dikaji, karena jika dibandingkan dengan lembaga pendidikan yang serupa di negara-negara lain, maka sistem pondok pesantren di Indonesia merupakan sistem pendidikan pertama yang ada dan mampu merespons tantangan-tantangan zamannya dengan sukses. Sementara itu, sistem pesantren yang dikembangkan oleh kaum sufi baik di Malaysia maupun Thailand bagian utara, sekarang ini senantiasa merana ditekan sistem sekolah ala Barat. Ini berarti tanpa disadari terdapat langkah-langkah strategis yang ditempuh oleh pondok pesantren dalam menjalin hubungan dengan masyarakat, ${ }^{10}$ termasuk fungsi public relations yang telah dijalankan di pondok pesantren.

Di antara pesantren yang masih mampu bertahan dan berkembang sampai sekarang adalah pondok pesantren salafiyah Sidogiri, Pasuruan. Hal ini sebagaimana pernyataan Saifulloh Naji yang mengatakan sebagai berikut:

Kalau shi'âr yang mengarah pada publikasi dan mempengaruhi orang lain, kami tegaskan bahwa di ponpes Sidogiri ini tidak pernah ada publikasi. Pesan dari para dewan mashâyikh, kami tidak diperkenankan untuk menyebarkan brosur, spanduk, dan lain-lain, bahkan nameboard untuk ponpes Sidogiri saja kami tidak memiliki. Namun, kami memiliki kunci utama dari public relations, yaitu kami memilih jalur sosialisasi melalui kiprah atau kbidmah. Kami penyambung lidah kepada masyarakat. Inilah salah satu cara public relations di pondok pesantren ini. ${ }^{11}$

\footnotetext{
7 Aya Sofia, et al., Pedoman Penyelenggaraan Pusat Informasi Pesantren (Jakarta: Departemen Agama RI-Proyek Pembinaan dan Bantuan Kepada Pondok Pesantren, 1985/1986), 41.

${ }^{8}$ Hasan Langgulung, Pendidikan Islam Menghadapi Abad ke-21 (Jakarta: Pustaka AlHusna, 1988), 75.

9 Ali Ma'shum, Ajakan Suci (t.tp.: LTN-NU DY, 1995), 108.

10 Abdurrahman Wahid, "Pondok Pesantren Masa Depan”, dalam Marzuki Wahid, Suwendi dan Saefuddin Zuhri (ed.), Pesantren Masa Depan Wacana Pemberdayaan dan Transformasi Pesantren (Bandung: Pustaka Hidayah, 1999), 19-20.

11 Saifullah Naji, Wawancara, Pasuruan, 25 Desember 2011.
} 
Fenomena tersebut di atas, menunjukkan bahwa public relations eksis dan berjalan di lingkungan pondok pesantren. Pesantren mendapatkan kepercayaan masyarakat berdasar orientasi non-profit, karena kepercayaan masyarakat diperoleh dari hasil/produk santri yang telah menuntut ilmu di pondok pesantren tersebut. Pesantren mampu mengubah masyarakat sekitarnya sebagai agent of social change, sehingga keberadaan pondok pesantren sebagai lembaga mendapatkan citra yang positif di masyarakat.

Artikel ini berusaha menyuguhkan bagaimana keberadaan public relations dan strategi public relations di pondok pesantren salafiyah Sidogiri, Pasuruan, Jawa Timur. Tujuannya untuk memberikan pemahaman deskriptif mengenai keberadaan public relations dan strategi membangun citra melalui public relations di pondok pesantren salafiyah Sidogiri. Secara teoritis kajian ini dapat memberikan perspektif yang luas terhadap strategi public relations di lembaga non-profit, yaitu pondok pesantren salafiyah. Sedangkan pada konteks substansial, penelitian ini mencoba mendialogkan antara teori membangun citra melalui identitas lembaga dan nilai-nilai yang dibangun oleh Rosady Ruslan dan teori tentang model public relations yang digagas oleh James Grunig and Todd Hunt.

\section{Definisi dan Model Public Relations}

Scott Cutlip mendefinisikan public relations sebagai fungsi manajemen yang membentuk dan memelihara relasi yang saling menguntungkan antara organisasi dengan publiknya. Keberhasilan atau kegagalan public relations ini tergantung bagaimana membentuk dan memelihara relasi yang saling menguntungkan itu. ${ }^{12}$

Lebih lanjut Edward L Bernays berpendapat bahwa public relations adalah upaya mendorong masyarakat untuk memiliki pemahaman dan etika yang baik; sedangkan dalam kamus Webster's Third New International Dictionary dinyatakan bahwa public relations adalah ilmu tentang seni yang mengembangkan pemahaman timbal balik dan kemauan yang baik; The British Institute of Public Relations menggarisbawahi bahwa public relations adalah upaya untuk membangun dan memelihara saling pengertian antara organisasi dengan publik.

Terdapat empat model public relations menurut James Grunig dan Todd Hunt, yaitu: 1). press agentry/publicity model, 2). public information

${ }^{12}$ Jefkins, Public Relations, 32. 
model, 3). two way asymmetric model, dan 4). two way symmetric model..$^{13}$ Adapun penjelasan dari keempat model tersebut adalah sebagai berikut.

\begin{tabular}{|c|c|c|c|c|}
\hline \multirow[b]{2}{*}{ Characteristic } & \multicolumn{4}{|c|}{ Model } \\
\hline & $\begin{array}{l}\text { Press } \\
\text { Agentry/pub } \\
\text { licity }\end{array}$ & $\begin{array}{l}\text { Public } \\
\text { Information }\end{array}$ & $\begin{array}{l}\text { Two-way } \\
\text { asymmetric }\end{array}$ & $\begin{array}{l}\text { Two-way } \\
\text { symmetric }\end{array}$ \\
\hline Purpose & Propaganda & $\begin{array}{l}\text { Dissemination } \\
\text { of } \\
\text { information }\end{array}$ & $\begin{array}{l}\text { Scientific } \\
\text { persuasion }\end{array}$ & $\begin{array}{l}\text { Mutual } \\
\text { understandin } \\
\mathrm{g}\end{array}$ \\
\hline $\begin{array}{l}\text { Nature of } \\
\text { communicatio } \\
\mathrm{n}\end{array}$ & $\begin{array}{l}\text { One-way: } \\
\text { complete } \\
\text { truth not } \\
\text { essential }\end{array}$ & $\begin{array}{l}\text { One-way: } \\
\text { truth } \\
\text { important }\end{array}$ & $\begin{array}{l}\text { Two-way: } \\
\text { imbalanced } \\
\text { effects }\end{array}$ & $\begin{array}{l}\text { Two-way: } \\
\text { balanced } \\
\text { effects }\end{array}$ \\
\hline $\begin{array}{l}\text { Communicati } \\
\text { on model }\end{array}$ & Source $\rightarrow$ rec. & Source $\rightarrow$ rec. & $\begin{array}{l}\text { Source } \rightarrow \text { rec. } \\
\text { feedback } \leftarrow\end{array}$ & $\begin{array}{l}\text { Group } \rightarrow \text { gro } \\
\text { up } \\
\leftarrow\end{array}$ \\
\hline $\begin{array}{l}\text { Nature of } \\
\text { research }\end{array}$ & $\begin{array}{l}\text { Little; } \\
\text { 'counting } \\
\text { house' }\end{array}$ & $\begin{array}{l}\text { Little; } \\
\text { readibility, } \\
\text { readership }\end{array}$ & $\begin{array}{l}\text { Formative; } \\
\text { evaliative of } \\
\text { attitudes }\end{array}$ & $\begin{array}{l}\text { Formatives; } \\
\text { evaluative of } \\
\text { understandin } \\
\mathrm{g}\end{array}$ \\
\hline $\begin{array}{l}\text { Leading } \\
\text { historical } \\
\text { figures }\end{array}$ & PT. Barnum & Ivy Lee & $\begin{array}{l}\text { Edward L. } \\
\text { Bernays }\end{array}$ & $\begin{array}{l}\text { Bernays, } \\
\text { educators, } \\
\text { profesional } \\
\text { leaders }\end{array}$ \\
\hline $\begin{array}{l}\text { Where } \\
\text { practised } \\
\text { today }\end{array}$ & $\begin{array}{l}\text { Sport, } \\
\text { theatre, } \\
\text { product } \\
\text { promotion }\end{array}$ & $\begin{array}{l}\text { Government, } \\
\text { non-profit } \\
\text { associations, } \\
\text { business }\end{array}$ & $\begin{array}{l}\text { Competitive } \\
\text { business, } \\
\text { agencies }\end{array}$ & $\begin{array}{l}\text { Regulated } \\
\text { business, } \\
\text { agencies }\end{array}$ \\
\hline $\begin{array}{l}\text { Estimated } \\
\text { percentage of } \\
\text { organizations } \\
\text { practising to } \\
\text { day }\end{array}$ & 15 & 50 & 20 & 15 \\
\hline
\end{tabular}

\section{Strategi Public Relations dalam Membangun Citra Lembaga Pendidikan}

Citra adalah sebuah pandangan mengenai suatu perusahaan atau instansi. Ia, citra, dihasilkan melalui penilaian objektif masyarakat atas tindakan, perilaku, dan etika instansi di tengah-tengah masyarakat. Citra merupakan kesan, perasaan, gambaran diri publik terhadap

13 James E. Grunig dan Todd Hunt, Managing Public Relations (Belmont, CA: Thompson Wadworth, 1984), 22; Alison Theaker, The Public Relations (London and New York: Routledge Taylor \& Francis Group, 2004), 11-14; dan Theodore J. Kowalski, Public Relations in School (New Jersey: Pearson, Merrill Prentice, 2004), 9. 
institusi, kesan yang dengan sengaja diciptakan dari suatu objek, orang, atau organisasi.

Dalam teori manajemen, pembangunan citra merupakan salah satu bagian yang terpisahkan dari strategi marketing. Strategi pencitraan adalah sebuah upaya yang tidak datang tiba-tiba dan tidak bisa direkayasa. Citra tidak dapat dibeli, namun didapat. ${ }^{14}$ Citra akan datang dengan sendirinya dari upaya yang ditempuh sehingga komunikasi dan keterbukaan perusahaan atau institusi merupakan salah satu faktor utama untuk mendapatkan citra yang positif. Hal ini memerlukan waktu yang panjang dan selalu belajar dari pengalamanpengalaman dalam melayani pengguna produk atau jasa. Sebagaimana pernyataan Michell yang menegaskan bahwa esensi pencitraan bagi institusi adalah dalam rangka repositioning dan merebut pangsa pasar publik. ${ }^{15}$

Istilah lain dari citra adalah image. Image adalah representasi dari pembangunan citra suatu lembaga, yang menyiratkan ke publik mengenai organisasi tertentu yang berkaitan dengan hal yang abstrak. Image berhubungan dengan simbol, persepsi, dan tingkah laku yang dikonstruksi oleh organisasi untuk disampaikan ke publik. Image mempengaruhi reputasi positif suatu lembaga. Reputasi lembaga tergantung pada image yang dibangun, ${ }^{16}$ dan menjadi aset penting dalam suatu lembaga. Suatu misal pada lembaga pendidikan tinggi, citra positif masyarakat akan didefinisikan dengan kuantitas mahasiswa, kualitas fakultas, kebutuhan mahasiswa, perpustakaan yang menunjang, seleksi administrasi, beasiswa dan block grant, pemenuhan alumni, fasilitas mutu, besarnya anggaran, reputasi inovasi, dan kualitas kepemimpinan. ${ }^{17}$ Unsur-unsur inilah yang membentuk citra lembaga. Demikian pula lembaga pendidikan Islam, termasuk pondok pesantren, citra akan terbentuk dengan sendirinya

\footnotetext{
14 M. Linggar Anggoro, Teori dan Profesi Kebumasan serta Aplikasinya di Indonesia (Jakarta: Bumi Aksara, 2008), 65.

15 Strategi pengembangan lembaga membutuhkan kiat yang disebut dengan riset pemasaran. Riset pemasaran adalah suatu riset yang ditujukan untuk mengumpulkan data yang akan digunkaan oleh pimpinan untuk merumuskan kebijakan pemasaran dan rencana usaha. Lihat Jhonatan E., Branding dalam Teori Marketing (Jakarta: t.p., 2009), 99.

16 D. Kazoleas, Y. Kim dan Moffit, "Institutional Image: a Case Study", Corporate Communications: An International Journal (2001), 205-206.

17 K.T. Theus, Public Relations Review (Academic Reputations: The Process of Formation and Decay, 1993), 277-291.
} 
apabila lembaga pendidikan tersebut memberikan pelayanan prima dan menunjukkan perilaku positif yang diterima di masyarakat.

Sedangkan menurut R. Abratt, citra dalam benak khalayak adalah akumulasi pesan yang terekam di alam pikiran mereka. Citra idealnya mencerminkan wajah dan budaya institusi sejalan dengan strategi institusi, jelas, dan konsisten. ${ }^{18}$ Citra sebagaimana pendapat Kotler dalam Sanaky, berarti sebuah kepercayaan, ide, dan impresi seseorang terhadap sesuatu. ${ }^{19}$ Sedangkan menurut Buchari, citra merupakan kesan, impresi, perasaan atau persepsi yang ada pada publik mengenai perusahaan atau insitusi suatu objek, orang atau lembaga. Citra merupakan gambaran yang ada dalam benak publik baik itu publik internal maupun eksternal tentang lembaga. ${ }^{20}$

Berdasar riset yang bisa dipertanggungjawabkan, beberapa lembaga telah berhasil menciptakan image sehingga bisa masuk segmen pasar publik secara militan. Hal tersebut dikarenakan terdapat beberapa indikator yang oleh Faradilah disebut sebagai tiga langkah strategis membangun image, yaitu: branding, position, dan differentition. ${ }^{21}$

Pertama, brand atau merek merupakan bagian terpenting dari institusi, karena merek akan memberikan image kepada lembaga. Kedua, position, merupakan penempatan lembaga pada posisi yang benar, pada level segmentasi. Agar lebih fokus, maka pihak lembaga harus mampu membidik segmentasi tertentu sesuai dengan tujuan yang telah ditargetkan. Ketiga, differensiasi, adalah sisi keunggulan yang dimiliki oleh pihak lembaga yang tidak dimiliki oleh lembaga lain. Dengan keunggulan ini akan mempermudah memberikan keterangan dan identitas pada khalayak atau dengan kata lain meletakkan posisi lembaga di masyarakat.

Pada dasarnya industri jasa kependidikan menghasilkan dua kategori, yaitu produk sepenuhnya yaitu jasa/pelayanan kependidikan dan produk parsial adalah lulusan. Produk-produk pendidikan sekolah terdiri dari jasa: kurikuler, penelitian, pengembangan kehidupan

\footnotetext{
18 Dadang Shugiana, Strategi Pemasaran Merek Corporate Pencitraan Produk (Bandung: Resensi, 2007).

19 Sanaky, Peran Public Relations dalam Kompetisi Dunia Usaha (Yogyakarta: Rake Sarasin, 2006).

20 Alma Buchari, Manajemen Pemasaran danPemasaran Jasa (Bandung: Alfabeta, 1992), 32.

${ }^{21}$ Faradilah R, Penerapan Marketing untuk Meningkatkan Prestasi Sekolah (Jakarta: UI Press, 2005).
} 
bermasyarakat, ekstrakurikuler, dan administrasi. Kelima produk inilah yang merupakan wilayah kendali penuh sekolah dan merupakan tolok ukur pelayanan sekolah oleh komponen pendidikan lainnya. ${ }^{22}$

Citra dibentuk dari identitas organisasi atau korporasi corporate identity. Oleh karena itu identitas adalah manifestasi visual dari citranya yang disampaikan melalui logo, produk, layanan, bangunan, alat tulis, seragam, dan benda-benda lain yang tampak tangible, yang dibuat oleh organisasi untuk berkomunikasi dengan khalayaknya. Selanjutnya khalayak akan mempersepsi citra sebuah organisasi berdasarkan pada pesan yang dikirimkan organisasi dalam bentuk identitas organisasi yang terlihat tersebut.

Citra merupakan daya magnet bagi sebuah produk. Image positif terhadap sesuatu akan muncul jika publik percaya trust dan selanjutnya yakin bahwa suatu produk bisa memenuhi tuntutan emosional mereka, karena trust dalam ilmu sosial merupakan social capital yang paling dominan dalam mempengaruhi perilaku masyarakat.

Cutlip menyatakan bahwa terdapat beberpa cara membentuk citra positif bagi organisasi atau lembaga, antara lain yaitu: 1) menciptakan public understanding, 2) menciptakan public confidence; 3) menciptakan public support; dan 4) menciptakan public corporate; yakni kerjasama dari publik terhadap organisasi atau lembaga. ${ }^{23}$

Sasaran pencitraan adalah bagaimana tercipta opini publik dalam kaitannya dengan keberadaan sebuah lembaga yang melayani atau memperjelas lembaga tersebut yang tergabung dalam istilah public relations atau hubungan masyarakat (humas). Mereka menjadi penghubung antara lembaga dan khalayak, dengan harapan penjelasan pesan-pesan dari public relations atau humas akan mampu mengubah citra publik terhadap institusi melalui media massa.

Ada hubungan sinergis antara kepercayaan, pendekatan manajer, dan respons masyarakat. Apabila kepercayaan tinggi, pendekatan aktif, maka menghasilkan respons yang positif dan begitu sebaliknya. ${ }^{24}$ Salah satu cara membangun citra lembaga pendidikan yaitu dengan cara

22 Daulat Tampubolon, "Pendidikan Bermutu untuk Semua", dalam Makalah Seminar Meningkakan Mutu Pendidikan Indonesia, 12 Mei 2005 (Jakarta: IBII, 2005).

23 Scott M. Coultip, Allen Center \& Gleen M. Broom, Effective Public Relations: Merancang dan Melaksanakan Kegiatan Kebumasan dengan Sukses, terj. Tri Wibowo (Jakarta: Prenada Media, 2006).

${ }^{24}$ Qomar, Manajemen, 190. 
mengelola hubungan yang baik dengan stakeholders, sehingga melalui hubungan yang baik dan strategis itu dapat mencapai hubungan yang baik dan strategis itu dapat mencapai tujuan lembaga pendidikan secara realistis.

Adapun citra yang berkaitan dengan lembaga pendidikan Islam pesantren akan terbangun dari trust khalayak melalui interaksi ${ }^{25}$ timbal balik antara khalayak dengan lembaga/institusi. Hal ini sebagaimana diungkapkan oleh Kotler dan Sanaky yang menyatakan bahwa citra adalah kepercayaan, ide, dan impresi seseorang terhadap sesuatu. ${ }^{26}$ Sedangkan konsep dasar untuk membangun citra menurut Rosady Ruslan adalah seperti diagram di bawah ini.

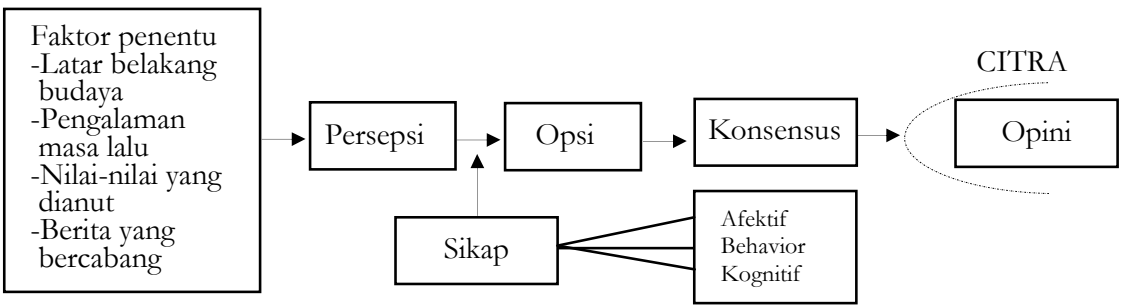

Gambar. Proses Image Bulding ${ }^{27}$

Sehubungan dengan konsep membangun citra tersebut di atas, implementasi pembangunan citra di pondok pesantren tidak terlepas dari opini publik yang dibangun dan juga sikap output yang terbentuk dari pondok pesantren tersebut. Namun demikian sikap dan karisma seorang kiai tetap menjadi mercusuar pondok pesantren dalam menjalin komunikasi dan berinteraksi guna mencari dukungan positif dari khalayak. Pembangunan citra pondok pesantren bisa diukur dari seberapa besar pendidikan pondok pesantren mampu memainkan peran pemberdayaan enpowerment dan mampu mentransformasikan nilai-nilai social society secara efektif dalam masyarakat. ${ }^{28}$ Latar belakang budaya dan nilai sebagai faktor penentu dari pesantren berupa nilainilai religius, keyakinan, budaya, dan norma perilaku yang dianggap bersifat tradisional oleh khalayak menjadi suatu hal yang memiliki nilai keunikan dan interest publik tersendiri dan harus tetap dipertahankan karena justru faktor penentu inilah yang menjadikan pesantren bisa

\footnotetext{
25 Shugiana, Strategi Pemasaran.

26 Sanaky, Peran Public Relations.

27 Zulkarnain Nasution, Manajemen Humas di Lembaga Pendidikan: Konsep, Fenomena, dan Aplikasinya (Malang: UMM Press, 2006), 25.

${ }^{28}$ Wahid, Pondok Pesantren, 76.
} 
diterima oleh masyarakat dengan memberikan label/citra positif. Faktor penentu tersebut merupakan landasan bagi perubahan dalam hidup pribadi atau kelompok, ${ }^{29}$ yang mana jika faktor-faktor penentu tersebut dihilangkan justru gaung pesantren akan redup.

\section{Keberadaan Alamiah Public Relations}

Keberadaan public relations dalam suatu lembaga pendidikan merupakan salah satu bagian dari manajemen yang merupakan komponen penyempurna dari suatu organisasi pendidikan atau pendidikan Islam. Suatu organisasi atau lembaga pendidikan, dalam menjalankan kerjanya sebaiknya melibatkan masyarakat. Merupakan suatu keniscayaan apabila dalam menjalin hubungan dengan masyarakat tanpa adanya public relations. Demikian pula yang terjadi di pondok pesantren. Diperlukan pengelolaan fungsi public relations dengan baik agar pondok pesantren dapat tetap eksis di tengah-tengah masyarakat. Hal tersebut sebagaimana dikemukakan oleh Maftukhin:

Kalau public relations diartikan bagaimana menjalin hubungan yang baik dengan publik yang meliputi masyarakat secara luas, unsur pemerintah maupun ormas, maka yang paling sukses dan berhasil adalah public relations yang dijalankan pondok pesantren. Walaupun ia, pondok pesantren, secara struktural tidak mencanangkan bidang/seksi public relations atau kehumasan, namun sebenarnya pondok pesantren justru telah menjalankan fungsi-fungsi dari public relations itu sendiri dan dalam realitanya pondok pesantren selama ini mampu berdampingan dengan unsur pemerintah dan mendapat dukungan dari masyarakat ${ }^{30}$

Hal senada juga dikatakan oleh Samsul Huda yang menyatakan bahwa:

Publik relations di pondok pesantren secara formal tidak ada. Adanya seksi humas dan informasi hanya memberikan informasi mengenai pondok kepada para santri, termasuk juga melayani para tamu. Kalau public relations dalam arti yang luas belum ada seksi tersendiri, namun secara fungsional sebenarnya makna public relations telah dilaksanakan oleh semua unsur yang terdapat di pondok pesantren. Kalau masalah perekrutan santri baru, ponpes tidak pernah memasang spanduk ataupun brosur, namun kami melakukan aksi langsung kepada masyarakat. Maka dari itu, dapat dikatakan bahwa kami tidak mempublikasikan secara langsung, namun kami telah menjalankan fungsi-fungsi public relations. ${ }^{31}$

${ }^{29}$ Stephen Robbins, Organizational Behavior (Mexico: Prentice Hall, 2003), 81.

30 Maftukhin, Wawancara, Pasuruan, 18 Mei 2011.

${ }^{31}$ Samsul Huda, Wawancara, Pasuruan, 8 September 2011. 
Abdul Ghafar juga menjelaskan bahwa:

Secara formal seksi kehumasan di pondok pesantren memang tidak ada, namun secara fungsional sebenarnya telah dilaksanakan oleh segenap elemen yang terdapat dalam pondok pesantren. Kami tegaskan bahwa di pesantren Sidogiri ini tidak pernah ada publikasi. Hal itu sudah pesan dari para dewan mashâyikh dan merupakan kultur budaya masa lalu. Kami sama sekali tidak diperkenankan untuk menyebar brosur, spanduk, dan lain-lain, bahkan papan nama untuk ponpes Sidogiri saja kami tidak memiliki. Bisa dilihat tidak ada satu pun papan nama tentang ponpes Sidogiri, karena kami lebih memilih sosialisasi daripada publikasi. ${ }^{32}$

Lebih lanjut Saifullah Naji menjelaskan:

Eksistensi public relations pesantren kami memang tidak ada. Bagi kami substansi public relations dapat kami terjemahkan sebagai shiâar. Pesantren kami melakukannya dengan terjun langsung di masyarakat. Kami tidak melakukan publikasi, tidak ada baliho, umbul-umbul, nameboard, leaflet atau apapun bentuk brosur-brosur tentang ponpes, karena yang kami lakukan adalah sosialisasi langsung di masyarakat. ${ }^{33}$

Dari pernyataan-pernyataan di atas, dapat ditegaskan bahwa keberadaan public relations secara struktural tidak ditemukan di pesantren Sidogiri, namun public relations jika dimaknai sebagai jalinan yang baik dengan masyarakat dan pihak manapun, maka pada hakikatnya pesantren telah melakukan hal itu. Setiap unsur yang ada di ponpes telah melakukan public relations. Hal ini terbukti dengan adanya jalinan atau hubungan yang baik antara ponpes dengan masyarakat, pemerintah maupun non pemerintah.

Terdapat seksi hubungan masyarakat (humas) dan informasi di pesantren Sidogiri yang bertugas memberikan layanan informasi mengenai kebijakan pesantren dan juga berinteraksi dalam hal pelayanan tamu yang berkunjung ke pesantren. Seksi ini bersifat internal pesantren, dan belum mengarah pada fungsi dari public relations secara makro. Public relations sendiri adalah bagian dari organisasi yang menjadi "jembatan komunikasi" antara sebuah institusi dengan publiknya sehingga tercipta pengertian bersama yang berdampak terhadap penciptaan citra positif dan dukungan dari publik terhadap eksistensi ponpes.

\footnotetext{
32 Abdul Ghofar, Wawancara, Pasuruan, 23 September 2011.

33 Saifullah Naji, Wawancara, Pasuruan, 16 September 2011.
} 
Salah satu alumni pondok Pesantren Sidogiri, Muhammad, mengemukakan:

Public relations diartikan sebagai upaya menjalin hubungan yang baik dengan dunia luar, baik itu masyarakat maupun unsur-unsur lain. Walaupun pondok pesantren secara struktural tidak membentuk bidang kehumasan, namun sebenarnya pondok pesantren justru telah menjalankan fungsi-fungsi kehumasan itu sendiri. Fungsi-fungsi tersebut biasanya diperankan oleh para santri, alumni, dan juga karisma kiai. ${ }^{34}$

Hal tersebut diperkuat oleh observasi yang peneliti lakukan, bahwa di Pondok Pesantren Sidogiri secara formal tidak ditemukan adanya organisasi yang menaungi public relations, namun fungsi public relations tersebut telah dijalankan oleh kiai, santri, maupun alumni. Aktivitas kiai, sebagai guru santri ataupun sebagai muballigh secara tidak langsung membawa almamater pondok pesantrennya, sehingga fungsi public relations dapat dijalankan. ${ }^{35}$

Lebih dalam lagi, mengenai hubungan pondok pesantren Sidogiri dengan masyarakat, Naji mengemukakan bahwa pondok pesantren Sidogiri menggunakan suatu pendekatan, yaitu:

Pendekatan yang kami lakukan pertama, cultural approach, yaitu pendekatan kultur atau budaya. Pesantren lebih melihat apa yang menjadi kebutuhan masyarakat, kemudian pesantren cenderung melengkapi dan mengayomi. Jadi, pesantren tidak memaksakan masyarakat harus berbuat seperti ini atau itu, tidak memaksa masyarakat untuk mengikuti ini atau itu, tetapi justru mengarahkan masyarakat lewat budayanya. Kedua, religious approach, yaitu pendekatan keagamaan melalui pendidikan dan sosial dengan berpegang pada nilai-nilai salaf, dan ketiga, economical approach, yaitu jiwa kewirausahaan melalui Bayt al-Mâl wa alTamwîl (BMT), Koperasi Pondok Pesantren (Kopontren), Air Minum dalam Kemasan (AMDK) "santri dan Giriway", PT Hasbi, PT Pustaka, Koperasi Agro, dan Bank Perkreditan Rakyat Sharî‘ah (BPRS) Ummu. ${ }^{36}$

Penjelasan Naji di atas memberikan pemahaman bahwa pondok pesantren masih tetap berada dalam kultur otentiknya, yaitu ciri khas salafiyah berupa pembelajaran kitab kuning dan pembentukan jiwa wirausaha. Dengan tetap berpijak pada nilai salaf inilah, santri tidak hanya disuruh membaca kitab dan mengaji saja, akan tetapi juga menelaah masalah-masalah kontekstual yang terjadi di masyarakat. Dengan menelaah kitab kuning dan mempelajarinya secara holistik,

34 Muhammad, Wawancara, Pasuruan, 27 Maret 2012.

35 Observasi, 27 September 2011.

36 Saifullah Naji, Wawancara, Pasuruan, 14 Oktober 2011. 
maka seorang santri akan mempunyai wawasan dan ilmu pengetahuan yang luas hingga akhirnya bermanfaat di tengah masyarakat. Ketika santri sudah memiliki bekal yang kuat inilah, maka potensi dan perilaku santri akan berdampak pada pelaksanaan public relations itu sendiri. Secara tidak langsung, pondok pesantren Sidogiri tersebut telah mengadakan public relations, walaupun secara formal tidak terdapat pengorganisasian yang menangani hal tersebut. Akhirnya dapat dikatakan, public relations di pondok pesantren Sidogiri ini bersifat natural, karena seluruh elemen yang terdapat di pondok pesantren, mulai dari kiai sampai dengan santri, bahkan alumninya secara otomatis telah menjalankan fungsi public relations tatkala mereka melakukan tugas pokok dan fungsinya, baik di internal maupun eksternal pondok pesantren.

Semua elemen pondok pesantren berusaha untuk menjalin hubungan baik dengan masyarakat luas. Sebagaimana yang dikutip oleh Onong bahwa, dalam public relations harus memenuhi dua aspek: pertama, sasaran public relations adalah publik internal dan publik eksternal. Publik internal adalah orang-orang yang berada atau tercakup dalam organisasi, sedangkan publik eksternal adalah orangorang yang berada di luar organisasi yang ada hubungannya dan yang diharapkan ada hubungannya. Kedua, kegiatan public relations adalah komunikasi dua arah timbal-balik (reciprocal two way traffic communications). Ini berarti bahwa dalam penyampaian informasi, baik yang mengarah ke publik internal maupun yang mengarah ke publik eksternal terjadi umpan balik. ${ }^{37}$

Hal ini nampaknya sesuai dengan salah satu konsep public relations yang dikemukakan oleh Ametambun, sebagaimana yang dikutip Daryanto, yaitu konsep partnership. Hubungan ini dapat diinterpretasikan sebagai hubungan proses timbal-balik di mana kebutuhan dan keinginan masyarakat juga menjadi kebutuhan dan keinginan lembaga pendidikan. ${ }^{38}$ Inilah salah satu bentuk kerjasama antara pondok pesantren dengan masyarakat.

${ }^{37}$ Effendy Onong Uchjana, Human Relations dan Public Relations (Bandung: Mandar Maju, 1993), 110.

38 Menurut Amatembun, konsep public relations terbagi menjadi lima bagian: konsep "menunggu", yaitu lembaga pendidikan hanya menunggu dan mengharapkan perhatian dan bantuan dari masyarakat; konsep preventif, yaitu kegiatan lembaga pendidikan hanya untuk mencegah hal-hal yang tidak diinginkan oleh masyarakat; konsep tanda bahaya kegiatan-kegiatan hubungan masyarakat terjadi apabila ada bahaya, misalnya kebakaran, sehingga lembaga pendidikan memerlukan bantuan 
Sebagaimana dikemukakan oleh Hadari Nawawi bahwa tugas public relations, yaitu pertama, memberikan informasi dan menyampaikan ide gagasan kepada masyarakat atau pihak-pihak yang membutuhkannya. Menyebarluaskan informasi dan gagasan-gagasan itu agar diketahui maksud atau tujuannya serta kegiatan-kegiatannya. Kedua, membantu pimpinan karena tidak dapat langsung memberikan informasi kepada masyarakat atau pihak-pihak yang memerlukannya. Ketiga, membantu pimpinan mempersiapkan bahan-bahan tentang permasalahan dan informasi yang akan disampaikan atau yang menarik perhatian masyarakat pada saat tertentu. Dengan demikian, pimpinan selalu siap dalam memberikan bahan-bahan informasi yang up to date. Keempat, membantu pimpinan dalam mengembangkan dalam rencana dan kegiatan-kegiatan lanjutan yang berhubungan dengan pelayanan kepada masyarakat public service sebagai akibat dari komunikasi timbal balik dengan pihak luar untuk penyempurnaan policy dan kegiatan yang dilakukan oleh organisasi. ${ }^{39}$

Di samping itu, ponpes Sidogiri memiliki jaringan alumni yang kuat. Bahkan nama pondok pesantren Sidogiri harum di tengahtengah masyarakat karena alumni pondok pesantren tersebut menjadi orang yang berguna di masyarakat. Hal ini nampaknya sesuai dengan salah satu hasil penelitian Layanan Riset Pendidikan dan Asosiasi Nasional Kepala Pendidikan Dasar di Alexandria, sebagaimana dikutip Burhanuddin, mengenai program pemanfaatan alumni. Hasil penelitianya menyatakan bahwa alumni suatu lembaga pendidikan yang mampu berkiprah di masyarakat, membawa nama harum almamaternya. ${ }^{40}$

Public relations di pondok pesantren tersebut juga dilaksanakan secara by perform. Performa yang ditunjukkan oleh figur seorang kiai di tengah-tengah publik, secara tidak langsung memberikan pengertian,

dengan masyarakat; konsep pameran sebuah lembaga pendidikan hanya memamerkan kegiatannya kepada masyarakat, tentu saja hal-hal yang dipamerkan hanya tertentu yang telah diseleksi.; konsep prestise, yaitu kegiatan lembaga pendidikan hanya untuk menonjolkan karirnya, mencari popularitas; konsep partnership, dan konsep social leadership. Lihat M. Daryanto, Administrasi Pendidikan (Jakarta: PT Rineka Cipta, 1998), 73.

${ }^{39}$ Hadari Nawawi, Administrasi Pendidikan (Jakarta: Gunung Agung, 1981), 74.

${ }^{40}$ Burhanuddin, et al., Manajemen Pendidikan: Analisis Substantif dan Aplikasinya dalam Institusi Pendidikan (Malang: UNM, 2003), 127-128. 
pemahaman, dan dukungan dari masyarakat, ${ }^{41}$ dan hal ini termasuk dalam kategori komunikasi persuasif untuk mempengaruhi persepsi masyarakat. ${ }^{42}$ Bahkan Cutlip menyatakan salah satu generalisasi yang aman dalam public relations adalah reputasi publik terhadap organisasi yang pada dasarnya banyak berasal dari perilaku pejabat seniornya. Ketika pemimpin bertindak, berbicara, maka berlangsunglah interpretasi dan gema yang diciptakan oleh public relations. Dengan demikian public relations melekat dalam diri seorang pemimpin atau manajer puncak. ${ }^{43}$

Gema yang diciptakan dan melekat dalam diri seorang pemimpin atau manajer puncak kiai ini sebagaimana pendapat Smith yang menyatakan bahwa you are as public relations on your self. Pernyataan Smith tersebut diaplikasikan oleh kiai, santri maupun alumni dengan cara menunjukkan performanya di masyarakat.

Fenomena ini berbeda dengan pondok pesantren modern (khalaf), di mana kebesaran pondok pesantren tidak semata-mata terpusat pada figur kiai yang karismatik, melainkan karena kebesaran lembaga dan sistem pondok pesantren tersebut. Dalam hal ini, pondok pesantren khalaf lebih mampu bertahan daripada pondok pesantren salaf. Bukti konkret adalah orang mengenal pondok pesantren salaf dari figur kiai. Contohnya pondok Lirboyo yang dikenal pertama adalah kiai Idris Marzuki, pondok Sidogiri yang dikenal pertama adalah kiai Nawawi, pondok Langitan, yang diketahui orang pertama kali adalah kiai Abdullah Faqih.

Hal ini berbeda dengan pondok modern Gontor, maka yang dikenal orang pertama kali adalah pesantren yang mengoptimalkan dua bahasa asing, Arab dan Inggris, dalam realitas pendidikannya, bukan pada sosok kiainya. Hal positif yang bisa dipetik dari pondok pesantren modern adalah ketika sistem manjerialnya telah berjalan baik, maka pondok pesantren modern akan lebih mampu bertahan karena pengaruh karisma kiai bukanlah satu-satunya hal yang menjadi faktor penentu keberlangsungan pondok pesantren tersebut, yang mana dalam hal ini berbeda dengan pondok pesantren salaf. Ketika pondok pesantren salaf kehilangan figur kiai, maka ketahanan pondok

${ }^{41}$ Anthony Davis, Everything You Should Know about Public Relations (Jakarta: PT. Elex Media Komputindo, 2005).

42 John E. Marston, Modern Public Relation (New York: McGraw-Hill, 1979), 6.

${ }^{43}$ Scott M. Cutlip, et al., Effective Public Relations: Merancang dan Melaksanakan Kegiatan Kehumasan dengan Sukses (Jakarta: PT. Indeks Kelompok Gramedia, 2005), 50. 
pesantren bisa melemah. Hal ini disebabkan karena masyarakat yang paternalistik merasa telah kehilangan figur yang senantiasa dituakan dianggap orang tua atau sesepub karena kedalaman ilmunya, sekaligus kehilangan figur yang harus dihormati dan dijadikan panutan/pemimpin.

\section{Strategi Membangun Citra Pondok Pesantren}

Dalam konteks penelitian ini, citra lembaga atau corporate image melekat pada lembaga pondok pesantren, terlebih pondok pesantren Sidogiri. Pesantren tersebut dibangun atas sejarah keberhasilan para tokoh pendirinya. Mereka membentuk karakter lembaga dan membangun identitas kelembagaan sehingga berhasil membangun citra positif. Citra lembaga yang terbangun atas sejarah keberhasilan para tokoh pendirinya dikenal karena memiliki organizational saga. ${ }^{44} \mathrm{Hal}$ ini sebagaimana pendapat Wilson yang menyatakan bahwa setiap organisasi pasti memiliki identitas diri. Artikulasi dari identitas tersebut tercermin dalam etos, tujuan, dan nilai-nilai organisasi. Identitas diri menunjukkan sense of individuality yang bisa membantu organisasi membedakan dirinya dengan organisasi lain dalam lingkup persaingan. Identitas ponpes Sidogiri tersebut tercermin dari sikap ketundukan terhadap nilai-nilai salaf yang diterapkan.

Citra sejarah dan riwayat lembaga yang gemilang, serta keberhasilan para tokoh sebelumnya juga keberhasilan para output dari lembaga dengan sendirinya akan berimplikasi kepada pembentukan citra lembaga atau corporate image. ${ }^{45}$ Sayid Sulaiman, putra dari Sunan Gunung Jati, selaku pendiri ponpes salafiyah Sidogiri, ${ }^{46}$ beserta keturunan selanjutnya menjadi pioner terhadap pencitraan ponpes. Demikian pula di ponpes Sidogiri, sejarah figur kiai juga berperan sebagai salah satu strategi membangun citra. Hal ini sebagaimana ungkapan Naji:

Memang tidak bisa kami pungkiri nama besar kiai Nawawi melekat di hati rakyat. Terbukti ketika acara hawl maupun akbîr al-sanah baik santri, alumni, masyarakat, bahkan pemerintah akan ikut ambil bagian dan meluangkan waktu, tenaga, dan biaya untuk kesuksesan acara tersebut.

\footnotetext{
${ }^{44}$ John Balmer and Alan Wilson, "Corporate Identity: There is more to it than Meets the Eye", International Studies of Management and Organization Journal (1998), 12 13.

45 M. Linggar Anggoro, Teori dan Profesi Kebumasan serta Aplikasinya di Indonesia (Jakarta: Bumi Aksara, 2000), 59-60.

46 http:/ /www.sidogiri.net (11 September 2011).
} 
Acara ini selain sebagai ajang yang bernuansa religius, secara tidak langsung juga bisa digunakan para santri, alumni, masyarakat, tokoh agama, maupun stakebolder untuk berkomunikasi dan berinteraksi secara langsung tentang segala hal (politik, ekonomi, sosial, dan lain-lain) sesuai dengan kapasitas dan kebutuhan masing-masing. Tanpa disadari ini adalah strategi public relations, dan perlu diketahui bahwa kami sama sekali tidak mengkondisikannya karena itu murni kesadaran mereka sendiri. ${ }^{47}$

Namun demikian, figur dan citra sejarah bukan satu-satunya faktor yang menjadikan citra pesantren meningkat. Selain citra pondok pesantren terbangun melalui sejarahnya, citra pesantren akan terbangun dengan sendirinya apabila output dari pondok pesantren tersebut mempunyai nilai guna di masyarakat. Selain itu, citra pondok pesantren akan terbangun dengan sendirinya jika pondok pesantren tersebut mempunyai kiprah di tengah-tengah masyarakat. Pandangan masyarakat umum terhadap kompetensi yang dimiliki santri/alumni akan menjadikan masyarakat mampu melakukan penilaian dan akhirnya citra baik akan terbangun dengan sendirinya.

Di samping itu, masyarakat banyak yang memondokkan anaknya di pondok pesantren, karena masyarakat percaya dan mengikuti semua yang dikatakan oleh seorang kiai, terutama kiai yang memimpin pondok pesantren yang besar seperti Sidogiri. Dengan demikian dapat dikatakan bahwa citra yang demikian disebut image building by charisma. Pencitraan positif sebagai akibat dari karisma ini sesuai dengan pendapat Cutlip yang menyatakan bahwa reputasi publik terhadap organisasi pada dasarnya banyak berasal dari perilaku pejabat seniornya pada saat mereka berada di posisi puncak. Ketika pimpinan bertindak dan berbicara maka berlangsunglah interpretasi dan gema yang diciptakan oleh figur tersebut sehingga mau tidak mau, pimpinan terikat pada fungsi public relations. ${ }^{48}$

Selaras dengan hal ini Abdurrahman Mas'ud mengatakan bahwa para santri menerima kepemimpinan kiai karena percaya pada konsep dalam masyarakat Jawa, yaitu berkah atau barakah yang didasarkan atas doktrin keistimewaan status seorang alim dan wali. ${ }^{49}$ Mereka meyakini bahwa orang yang alim maupun wali memiliki kemampuan

\footnotetext{
47 Saifullah Naji, Wawancara, 11 Desember 2011.

${ }^{48}$ Cutlip, et al., Effective, 50.

49 Abdurahman Mas'ud, Intelektual Pesantren: Perhelatan Agama dan Tradisi (Yogyakarta: LKiS, 2004), 13.
} 
istimewa yang tidak dimiliki orang pada umumnya sehingga menerima kepemimpinannya sebagai keniscayaan. Kepercayaan masyarakat dan santri terhadap karâmah kiai biasanya sangat kuat. Dalam masyarakat semacam ini, kiai dianggap sebagai bapak yang selalu mendidik dan tidak mungkin menyesatkan, sehingga mereka menaruh kepercayaan penuh padanya, ${ }^{50}$ namun, tradisi tersebut agak luntur di kalangan santri yang melanjutkan studinya di perguruan tinggi.

Akhlaq baik yang ditunjukkan para alumni merupakan salah satu alat yang ditunjukkan untuk membangun citra. Dengan menunjukkan akhlaq yang baik, maka alumni dapat menunjukkan kiprahnya di masyarakat. Pondok pesantren dipercaya masyarakat sebagai lembaga yang mampu membangun akhlaq atau karakter yang baik, yang hal itu sulit dilakukan oleh lembaga-lembaga yang lainnya. Padahal pengembangan karakter sementara ini direalisasikan dalam pelajaran agama, pelajaran kewarganegaraan, atau pelajaran lainnya, yang program utamanya cenderung pada pengenalan nilai-nilai secara kognitif, dan mendalam sedikit sampai ke penghayatan nilai secara afektif. Realitas ini menguatkan pendapat Anggoro yang menyatakan bahwa citra dan reputasi itu tidak bisa dibeli, tetapi citra itu didapat. ${ }^{51}$

Perolehan citra dan reputasi positif dari masyarakat bukan berarti tanpa adanya suatu usaha dari pondok pesantren. Di pesantren Sidogiri, citra pondok pesantren dibangun dengan lima cara, antara lain: alumni, ekonomi, media, pendidikan, sosial, dakwah, dan branding. ${ }^{52}$ Alumni berperan penting dalam membangun citra di pondok pesantren Sidogiri. Walaupun mereka sudah menjadi alumni, namun hubungan emosional dengan para kiai masih terjalin.

50 Qomar, Manajemen, 64.

51 Anggoro, Teori dan Profesi Kehumasan, 65.

52 Pondok Pesatren Sidogiri membangun citra lembaga melalui 5 cara, antara lain: (1) Alumni, dengan mengadakan pengajian keliling kota/kabupaten alumni dengan masyarakatnya. Hal ini untuk mendidik hati alumni untuk tetap berjiwa santri walaupun sudah menjadi alumni, hawl, Ikatan Alumni Sidogiri; (2) Ekonomi, melalui BMT dan Kopontren. Dua lembaga ini memang perintisnya murni dari alumni. Kami menanamkan perilaku siddîq dan amânah karena kalau dua sifat tersebut sudah terpatri, selanjutnya tinggal menggodok sikap fatânah dan tablìgh; (3) media, terdapat empat belas media baik cetak maupun non-cetak berbasis IT; (4) Sosial, melalui media pendidikan dan dakwah berupa lajnah murâja'ah, guru tugas, pengiriman santri untuk studi lanjut ke beberapa perguruan tinggi; serta yang terakhir (5) branding, yaitu brand 'santri' untuk merk kemasan air minum mineral yang dikelola pondok pesantren dan merk 'Sidogiri' untuk Kopontren dan sarung. Saifullah Naji, Wawancara, Pasuruan, 16 Oktober 2011. 
Nampaknya, implikasi dari label "santri" bagi seseorang yang sedang maupun telah selesai menuntut ilmu tersebut berimbas pada loyalitas mereka terhadap figur pengampu pesantren atau kiai. Hal ini sebagaimana penjelasan Sholeh sebagai berikut:

Kami memang mendidik para santri dengan hati, sehingga selalu ada ikatan emosional walaupun mereka sudah menjadi alumni dari pesantren ini. Bahkan mereka tetap disebut sebagai santri, karena sebulan sekali kami mengadakan ngaji rutin bagi para alumni hingga akhirnya masyarakat umum juga ada yang ikut bergabung. Ini adalah sarana untuk menjaga hubungan emosional antara dewan mashâyikh (majelis keluarga) dengan "santri" walaupun sudah menjadi alumni. ${ }^{53}$

Di samping itu, "guru tugas", yang dikirim oleh pesantren untuk mengabdi ke berbagai daerah, juga usaha untuk membangun citra selain label image branding yang ditunjukkan di atas. Nilai guna yang ditunjukkan santri, alumni maupun segenap elemen pesantren di masyarakat merupakan strategi untuk membangun citra pesantren. Hal ini sebagaimana pernyataan Mujbir:

Guru tugas rata-rata mengabdi satu tahun di suatu madrasah tertentu dan atas permohonan madrasah yang ditempati tersebut. Tahun ini pesantren telah mengirim 600-an santri. Pengiriman ke pulau Jawa, Bali, Sulawesi, Kalimantan, Sumatera, dan pernah pula ke Aceh. Setiap tanggal 14 Syawal sudah menjadi jadwal kami memberangkatkan guru tugas. Dasarnya adalah pemohonan dari daerah. Pengoordinasiannya tergantung pada permohonan daerah yang ditempati. Kalau permintaan sedikit, maka yang kami kirim yang sesuai permintaan tersebut. ${ }^{54}$

Di sisi lain, pesantren Sidogiri mempunyai nilai-nilai yang kuat dan berakar dalam budaya dan bentuk ritual yang sudah mapan. ${ }^{55}$ Sesuai dengan teori yang dikemukakan Robbins, latar belakang budaya dan nilai adalah faktor penentu eksistensi sebuah institusi, maka pesantren dalam hal ini juga memupuk nilai-nilai tersebut baik dari nilai-nilai religiusitas, keyakinan, budaya, dan norma perilaku yang dianggap bersifat tradisional. Nilai-nilai inilah yang dianggap baik oleh publik tersendiri dan karenanya ia harus tetap dipertahankan karena ia menjadi faktor penentu diterimanya pesantren oleh masyarakat dalam citranya yang positif. $^{56}$

\footnotetext{
${ }^{53}$ Sholeh, Wawancara, Pasuruan, 26 September 2011.

${ }^{54}$ Mujbir, Wawancara, Pasuruan, 28 September 2011.

55 "Profil Pondok Pesantren Sidogiri", dalam http://www.sidogiri.co.id.

${ }^{56}$ Robbins, Organizational Behavior, 81.
} 
Citra yang dibentuk melalui identitas adalah manifestasi visual yang disampaikan melalui simbol, produk, layanan, bangunan, alat tulis, seragam, dan benda-benda lain yang tampak tangible, yang dibuat oleh organisasi untuk berkomunikasi dengan khalayaknya. Selanjutnya khalayak akan mempersepsi citra sebuah organisasi berdasarkan pada pesan yang dikirimkan organisasi dalam bentuk identitas organisasi yang terlihat tersebut.

Benang merah yang dapat penulis ambil adalah strategi yang digunakan pondok pesantren di atas dalam membangun citra adalah strategi persuasif, yang meliputi:

a. Informasi atau pesan yang disampaikan harus berdasarkan pada fakta dan sesuai dengan kebutuhan masyarakat.

b. Public relations sebagai komunikator dan sekaligus mediator berupaya membentuk sikap dan pendapat yang positif dari masyarakat melalui rangsangan atau stimulasi.

c. Menyuguhkan produk yang terjamin dan mempunyai nilai guna dalam masyarakat. ${ }^{57}$

Adapun pesantren Sidogiri menerapakan fungsi public relations-nya sebagai berikut:

1. Personal network. Seseorang yang menjalankan networking didominasi oleh para alumni yang bisa menceritakan realitas aktivitas yang dilaksanakan selama di pesantren tanpa ada sesuatu yang dilebihkan ataupun dikurangi.

2. Quality product network. Para alumni lulusan dari pondok pesantren memiliki kiprah di masyarakat. Kebanyakan dari alumni santri minimal mereka sebagai figur yang disegani di masyarakat karena keilmuannya. Peran serta para alumni turut memberikan corak dan penilaian tersendiri di masyarakat, sehingga mampu mempengaruhi orang lain untuk tertarik dengan ponpes.

Dengan adanya network yang terbangun tersebut, maka pesantren Sidogiri tersebut akan terjaga eksistensinya dan akan mempunyai citra positif di mata masyarakat. Selain itu pembangunan citra pondok pesantren bisa diukur dari seberapa besar pendidikan pondok pesantren mampu memainkan peran pemberdayaan atau enpowerment dan mampu mentransformasikan nilai-nilai social society secara efektif dalam masyarakat. ${ }^{58}$

${ }^{57}$ Yasir Ghofar, Wawancara, Pasuruan, 24 Nopember 2011.

58 Marzuki Wahid, “Pondok Pesantren dan Penguatan Civil Society”, Aula, Vol. 22, No. 2 (Februari, 2000), 76. 
Di sisi lain membangun citra juga dilakukan dengan word of mouth (WOM) yaitu dengan saling memuji antar-kiai. ${ }^{59}$ Di tingkat bawah, konsep WOM ini juga diterapkan oleh seluruh elemen yang ada di pesantren, bahkan para alumni ketika mereka berinteraksi dengan masyarakat juga menggunakan komunikasi ini. WOM merupakan penyampaian informasi secara "getok tular" antar-individu. Peran WOM ini mengalahkan iklan yang ada di media. ${ }^{60}$ Menurut penelitian ini WOM lebih efektif karena melalui WOM informasi yang diberikan lebih objektif, ada pengaruh emosional karena berhadap-hadapan langsung, yang akhirnya akan "tersebarluaskan", dan khalayak percaya. Hal ini tidak ubahnya dengan peran santri maupun alumni, ketika mereka berkiprah di masyarakat, mereka adalah jendela pesantren. Apapun informasi mengenai pesantren bisa didapat melalui santri maupun alumni. Ketika para santri maupun alumni berkiprah di masyarakat, mereka menjadi penghubung antara lembaga dan khalayak, membawa perilaku dan kiprahnya di masyarakat merupakan cerminan dari citra ponpes. Kiprah di masyarakat merupakan penjelasan pesan-pesan dari public relations atau humas yang akhirnya akan mampu mengubah citra publik terhadap institusi atau perusahaan melalui media massa.

Secara lebih jelas strategi membangun citra pondok pesantren salafiyah tersebut dapat dilihat dari skema berikut.

\section{Penutup}

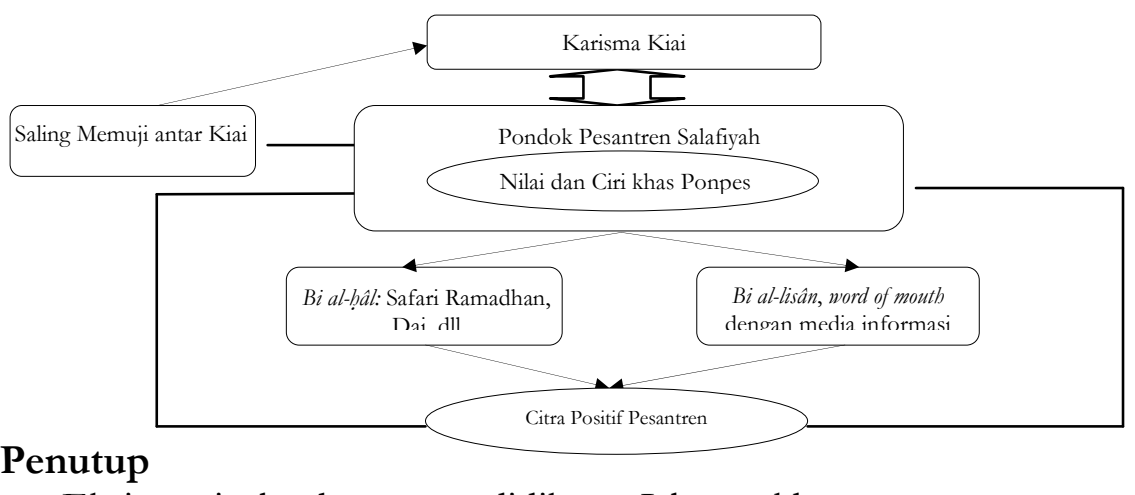

Eksistensi lembaga pendidikan Islam, khususnya pesantren Sidogiri yang mampu bertahan hingga saat ini, tidak bisa dipungkiri salah satu penyebabnya adalah berjalannya public relations di lingkungan

\footnotetext{
${ }^{59}$ Khabir, Wawancara, Pasuruan, 17 Januari 2012.

${ }^{60}$ Harry Puspito, "Kalahnya Pengaruh Iklan ATL TV, Radio, dan Cetak Dibanding Medium Word of Mouth (WOM)", Marketing Mix (11 April-10 Mei, 2007).
} 
pesantren tersebut. Walaupun keberadaan public relations di pesantren Sidogiri secara formal tidak ada, namun fungsi public relations berjalan dengan alamiah melalui jaringan alumni, di samping karisma para kiai dan pendirinya.

Dalam membangun citra pondok pesantren, strategi public relations yang dipilih tidak dilakukan dengan kegiatan publikasi secara terangterangan, karena publikasi lewat cara pengabdian alumni atau khidmah di masyarakat jauh lebih efektif. Melalui pengabdian langsung di masyarakat, pondok pesantren justru telah menunjukkan kepada publik bahwa mereka telah menjalankan proses public relations mulai dari how to integrate, how to inform, how to perfome, dan how to persuade, baru kembali lagi ke how to integrate. Cara public relations seperti ini bersifat circle sehingga terintegrasi.

Pelaksanaan public relations pondok pesantren salafiyah ini, secara otomatis akan membangun citra positif pondok pesantren di hadapan publik, walaupun tidak bisa dipungkiri citra positif pondok pesantren terbangun tidak terlepas dari tokoh pendirinya. Identitas pondok pesantren dengan budaya dan tradisinya, nilai-nilai salafiyah, kiai karismatik sebagai personal branding, santri, kitab kuning, sarung dan kopyah sebagai brand pondok pesantren salafiyah merupakan daya dukung pesantren tetap bisa bertahan hingga saat ini. Daya dukung dan daya tahan pesantren terimplementasikan dalam integrasi aktivitas pondok pesantren dengan berbagai program yang dibutuhkan masyarakat. Strategi public relations yang by action inilah yang menjadikan pondok pesantren mampu bertahan dan mendapat citra positif dari masyarakat, karena pondok pesantren mampu melakukan pendekatan secara kultural dan dan religius di tengah-tengah masyarakat.

\section{Daftar Rujukan}

Anggoro, M. Linggar. Teori dan Profesi Kehumasan serta Aplikasinya di Indonesia. Jakarta: Bumi Aksara, 2008.

Ardianto, Elvinaro. Public Relations Suatu Pendekatan Praktis: Kiat Menjadi Komunikator dalam Berbubungan dengan Publike dan Masyarakat. Bandung: Pustaka Bani Quraisy, 2004.

Azra, Azyumardi. "Surau di Tengah Krisis: Pesantren dan Perspektif Masyarakat", dalam Dawam Rahardjo (ed.), Pergulatan Dunia Pesantren Membangun dari Bawah. Jakarta: LP3ES, 1985.

Balmer, John dan Wilson, Alan. "Corporate Identity: There is more to it than Meets the Eye", International Studies of Management and Organization Journal, 1998. 
Buchari, Alma. Manajemen Pemasaran dan Pemasaran Jasa. Bandung: Alfabeta, 1992.

Burhanuddin, et al. Manajemen Pendidikan: Analisis Substantif dan Aplikasinya dalam Institusi Pendidikan. Malang: UNM, 2003.

Canfield, Bertrand R. Public Relations: Principles, Cases, and Problems. Homewood: Illinois Irwin, 1969.

Coultip, Scott M., Center, Allen. \& Broom, Gleen M. Effective Public Relations: Merancang dan Melaksanakan Kegiatan Kehumasan dengan Sukses, terj. Tri Wibowo. Jakarta: Prenada Media, 2006.

Daryanto, M. Administrasi Pendidikan. Jakarta: PT Rineka Cipta, 1998.

Davis, Anthony. Everything You Should Know About Public Relations. Jakarta: PT. Elex Media Komputindo, 2005.

E. Jhonatan. Branding dalam Teori Marketing. Jakarta: t.p., 2009.

Faradilah, R. Penerapan Marketing untuk. Meningkatkan Prestasi Sekolah. Jakarta: UI Press, 2005.

Ghofar, Abdul. Wawancara. Pasuruan, 23 September 2011.

Ghofar, Yasir. Wawancara. Pasuruan, 24 Nopember 2011.

Grunig, James E. dan Hunt, Todd. Managing Public Relations. Belmont, CA: Thompson Wadworth, 1984.

Haidar, Ali. Nabdlatul Ulama dan Islam di Indonesia: Pendekatan Fiqh dalam Politik. Jakarta: PT. Gramedia Pustaka Utama, 1994.

Http://www.sidogiri.net.

Huda, Samsul. Wawancara. Pasuruan, 8 September 2011.

Jefkins, Frank. Public Relations, terj: Aris Munandar. Jakarta: Erlangga, 1992.

Kazoleas, D., Kim, Y., \& Moffit. "Institutional Image: a Case Study", Corporate Communications: An International Journal, 2001.

Khabir. Wawancara. Pasuruan, 17 Januari 2012.

Kowalski, Theodore J. Public Relations in School. New Jersey: Pearson, Merrill Prentice, 2004.

Langgulung, Hasan. Pendidikan Islam Menghadapi Abad ke-21. Jakarta: Pustaka Al-Husna, 1988.

Ma'shum, Ali. Ajakan Suci. t.t.: LTN-NU DY, 1995.

Maftukhin. Wawancara. Pasuruan, 18 Mei 2011.

Marston, John E. Modern Public Relation. New York: McGraw-Hill, 1979. 
Mas'ud, Abdurahman. Intelektual Pesantren: Perhelatan Agama dan Tradisi. Yogyakarta: LKIS, 2004.

Muhammad. Wawancara. Pasuruan, 27 Maret 2012.

Mujbir. Wawancara. Pasuruan, 28 September 2011.

Naji, Saifullah. Wawancara. Pasuruan, 11 Desember 2011.

-----. W awancara. Pasuruan, 16 Oktober 2011.

Nasution, Zulkarnain. Manajemen Humas di Lembaga Pendidikan: Konsep, Fenomena, dan Aplikasinya. Malang: UMM Press, 2006.

Nawawi, Hadari. Administrasi Pendidikan. Jakarta: Gunung Agung, 1981.

Puspito, Harry. "Kalahnya Pengaruh Iklan ATL TV, Radio dan Cetak Dibanding Medium Word of Mouth (WOM)", Marketing Mix, 11 April-10 Mei, 2007.

Qomar, Mujamil. Manajemen Pendidikan Islam: Strategi Baru Pengelolaan Lembaga Pendidikan Islam. Jakarta: Erlangga, 2007.

Robbins, Stephen. Organizational Behavior. Mexico: Prentice Hall, 2003.

Sanaky. Peran Public Relations dalam Kompetisi Dunia Usaha. Yogyakarta: Rake Sarasin, 2006.

Saridjo, Marwan, et. al. Sejarah Pondok Pesantren di Indonesia. Jakarta: Dharma Bhakti, 1982.

Sholeh. Wawancara. Pasuruan, 26 September 2011.

Sholz. "Definisi Public Relations", dalam www. gemaserasi.web .id, 26 Desember 2011.

Shugiana, Dadang. Strategi Pemasaran Merek Corporate Pencitraan Produk. Bandung: Resensi, 2007.

Sofia, Aya, et al. Pedoman Penyelenggaraan Pusat Informasi Pesantren. Jakarta: Departemen Agama RI-Proyek Pembinaan dan Bantuan Kepada Pondok Pesantren, 1985/1986.

Sunyoto. "Pondok Pesantren dalam Alam Pendidikan

Nasional", dalam M. Dawam Rahardjo (ed.). Pesantren Pembaharuan. t.t.: LP3ES, 1995.

Tampubolon, Daulat. "Pendidikan Bermutu untuk Semua", dalam Seminar Meningkakan Mutu Pendidikan Indonesia, 12 Mei 2005. Jakarta: IBII, 2005.

Theaker, Alison. The Public Relations. London and New York: Routledge Taylor \& Francis Group, 2004. 
Theus K.T. Public Relations Review. Academic Reputations: The Process of Formation and Decay, 1993.

Tolkhah, Imam dan Barizi. Membuka Jendela Pendidikan-Mengurai Akar Tradisi. Jakarta: PT. Raja Grafindo Persada: 2004.

Uchjana, Effendy Onong. Human Relations dan Public Relations. Bandung: Mandar Maju, 1993.

Wahid, Abdurrahman. "Pesantren sebagai Subkultur", dalam M. Dawam Rahardjo (ed.), Pesantren dan Pembaharuan. t.t.: LP3ES, 1995.

------. "Pondok Pesantren Masa Depan", dalam Marzuki Wahid, Suwendi dan Saefuddin Zuhri (ed.), Pesantren Masa Depan Wacana Pemberdayaan dan Transformasi Pesantren. Bandung: Pustaka Hidayah, 1999.

Wahid, Marzuki. "Pondok Pesantren dan Penguatan Civil Society", Aula, Vol. 22, No. 2, Februari, 2000. 